\title{
Enrichment of microbial abundance in the sea-surface microlayer over a coral reef: implications for biogeochemical cycles in reef ecosystems
}

\author{
Ryota Nakajima $^{1, *}$, Kenji Tsuchiya ${ }^{2}$, Nobuyuki Nakatomi ${ }^{2}$, Teruaki Yoshida ${ }^{3}$, \\ Yuya Tada ${ }^{4}$, Fumie Konno ${ }^{2}$, Tatsuki Toda ${ }^{2}$, Victor S. Kuwahara ${ }^{2}$, Koji Hamasaki ${ }^{5}$, \\ Bin Haji Ross Othman ${ }^{3}$, Thirukanthan C. Segaran ${ }^{5}$, Abdul Wahid Mohd Effendy ${ }^{5}$ \\ ${ }^{1}$ Marine Biodiversity Research Program, Institute of Biogiosciences, Japan Agency for Marine-Earth Science and Technology \\ (JAMSTEC), 2-15 Natsushima-cho, Kanagawa 237-0061, Japan \\ ${ }^{2}$ Graduate School of Engineering, Soka University, 1-236 Tangi-cho, Hachioji, Tokyo 192-8577, Japan \\ ${ }^{3}$ Marine Ecosystem Research Centre, Faculty of Science and Technology, Universiti Kebangsaan Malaysia, 43600 Bangi, \\ Selangor, Malaysia \\ ${ }^{4}$ Graduate School of Environmental Science, Hokkaido University, N10W5, Kita- ku, Sapporo, Hokkaido 060-0810, Japan \\ ${ }^{5}$ Atmosphere and Ocean Research Institute, The University of Tokyo, 5-1-5 Kashiwanoha, Kashiwa, Chiba 277-8564, Japan \\ ${ }^{6}$ Institute of Marine Biotechnology, Universiti Malaysia Terengganu, 21030 Kuala Terengganu, Terengganu, Malaysia
}

\begin{abstract}
In order to test the hypothesis that the microbial enrichment in the sea-surface microlayer (SML) over coral reefs is significant, we investigated the abundance and production of the microbial community in the SML and sub-surface water (SSW) at a fringing coral reef of Malaysia. Samples were taken at 2 coral sites with different live coral coverage as well as one offshore site. We detected substantially high enrichment factors (EFs) in abundance (where EF = SML/SSW: the ratio of microbial abundance in the SML relative to SSW) for all biological groups at all sites: up to 6.0 for heterotrophic bacteria, 4.2 for cyanobacteria, 18.8 for autotrophic nanoflagellates and 22.6 for heterotrophic nanoflagellates. We also found that the enrichment factors of microorganisms in coral reefs were remarkably higher than in other marine ecosystems, and a higher concentration of microorganisms was observed in the higher coral coverage site, probably due to higher organic matter released by corals. The higher microbial abundance in the SML over coral reefs may enhance gaseous exchange and carbon flow in the food web through the air-sea interface.
\end{abstract}

KEY WORDS: Sea-surface microlayer $\cdot \mathrm{SML} \cdot$ Bacteria $\cdot$ Flagellates $\cdot$ Coral coverage

\section{INTRODUCTION}

The sea-surface microlayer (SML) is the thin boundary layer between the atmosphere and ocean, with a typical thickness of 10 to $250 \mu \mathrm{m}$ (Liss \& Duce 1997). It is also called 'surface film' or 'surface skin'. The SML is generally enriched in both dissolved and particulate organic matters as a result of the accumulation of organic matter at this air-sea interface by diffusion, adhesion to rising bubble plumes, convection and up- welling of sub-surface water, and particle deposition from the air (Liss \& Duce 1997). Wind-generated mixing could also be considered as a renewal mechanism, thereby increasing the vertical transport of potential SML material to the surface (Jarvis 1967, Liss \& Duce 1997, Obernosterer et al. 2005).

The SML has potentially significant effects on global climate change. Through this thin organic film, the atmosphere and the oceans mutually exchange various gases, which are critical to global ele- 
ment cycles and climate change (Liss \& Duce 1997). The enrichments of organic compounds in the SML suppress gas exchange processes by slower molecular diffusion and reduce gas transfer velocities by reducing the wave slopes (Frew et al. 2004).

The SML is also an aggregate-enriched biofilm environment with distinct microbial communities (reviewed by Cunliffe et al. 2009, 2013). Extensive research has shown that the SML contains elevated concentrations of heterotrophic- and autotrophic microorganisms including bacteria, cyanobacteria, flagellates and algae (e.g. Taguchi \& Nakajima 1971, Sieburth et al. 1976, Harvey \& Young 1980, Garabétian 1990, Agogué et al. 2004, Obernosterer et al. 2008, Santos et al. 2011). Concentrations of these microorganisms are generally 1 to 10 times greater at the SML than in the sub-surface water (SSW) (Table 1). Although comparatively fewer studies exist on microbial activity at the SML (reviewed by Obernosterer et al. 2005), it is apparent that microbial activity and metabolism at the SML can regulate airsea gas exchange, as they control the exchange of $\mathrm{CO}_{2}$ across the surface layer $(\sim 2 \mathrm{~cm})$ (Calleja et al. 2005). Thus, the significance of the microbial community in the SML has recently been reaffirmed. An important focus of recent microlayer research has been to establish the specific role of microbial communities and how these may vary in space and time at the air-sea interface (Cunliffe et al. 2011). At present, most studies on the microorganisms in the SML have been conducted in the open ocean and coastal or neritic waters in temperate regions (Table 1), but studies from tropical coastal waters are scarce and those from coral reef waters are not available.

In coral reef ecosystems, scleractinian corals release a large amount of organic matter (primarily carbohydrates; Wild et al. 2010) into ambient seawater (Crossland 1987). The photosynthetically fixed carbon translocated to the coral host from endosymbiotic zooxanthellae represents a primary source of energy for scleractinian corals (Falkowski et al. 1984, Davies 1991, Lesser et al. 2000). However, corals exude up to half of the organic carbon provided by their zooxanthellae into the surrounding water (e.g. Crossland et al. 1980, Davies 1984, Muscatine et al. 1984) for shedding of sediments, feeding, defense against pathogens, protection against UV radiation, and desiccation resistance (reviewed by Wild et al. 2004a). This organic matter is often referred to as coral mucus. More than half of the released coral mucus immediately dissolves in the water (reviewed by Nakajima et al. 2010), while a less-soluble fraction of gel-like mucus forms transparent filaments and strings that become suspended in the water column (Wild et al. 2004b, Naumann et al. 2009). The enclosed gas bubbles in the gel-like mucus give positive buoyancy, and the mucus suspension slowly ascends to the sea surface (Wild et al. 2004b). Passing through the water column, its sticky surface traps various organic particles, such as bacteria and algal cells, and becomes enriched in microorganisms (Naumann et al. 2009). The enriched mucus aggregates and then accumulates at the water surface (Wild et al. 2004b). We therefore hypothesize that coral mucus contributes to the enrichment of organic matter and microorganisms at the air-sea interface. Consequently, a more abundant and distinct microbial community may exist in the SML over coral reef waters compared to other marine ecosystems. Moreover, a higher coral coverage in an area can mean a higher organic matter (coral mucus) input, which may result in a more stimulated microbial community at the air-sea interface compared to areas with lower coral coverage. In the present study, we investigated the abundance and production of the microbial community in the SML and SSW at sites with different live coral coverage. Our interests in this study were to examine (1) How enriched is the abundance and production of microorganisms in the SML compared to SSW over coral reefs? (2) Does microbial abundance and production vary with coral cover? and (3) How does the microbial biomass in the SML of coral reefs compare with other marine ecosystems?

\section{MATERIALS AND METHODS}

\section{Study sites}

The study was performed at a fringing coral reef $\left(05^{\circ} 36^{\prime} 77-95^{\prime \prime} \mathrm{N}, 103^{\circ} 03^{\prime} 44-54^{\prime \prime} \mathrm{E}\right)$ at Bidong Island, Malaysia for 3 sampling days on 6-8 June 2011. SML sampling was conducted in the morning from 10:00 $\mathrm{h}$ to $11: 30 \mathrm{~h}$ every day at 2 coral sites and one offshore site (Fig. 1). The coral sites were categorized into higher live coral coverage (HCC, $76.9 \pm 10.2 \%$ ) and lower coral coverage (LCC, $29.9 \pm 31.1 \%$ ) and were located about $300 \mathrm{~m}$ apart. The corals were dominated by Acropora nobilis and A. formosa at both sites, accounting for $>90 \%$ of the live corals. The depths at both sites were 2.2 to $2.5 \mathrm{~m}$ at high tide. The offshore site, located about $500 \mathrm{~m}$ from the coast, was $15 \mathrm{~m}$ deep. During the fieldwork, the surface water temperature ranged from $29.5^{\circ} \mathrm{C}$ to $30.5^{\circ} \mathrm{C}$ (overall mean $\pm \mathrm{SD}=30.1 \pm 0.3^{\circ} \mathrm{C}$ ). Weather conditions were stable, and the sea condition was calm 


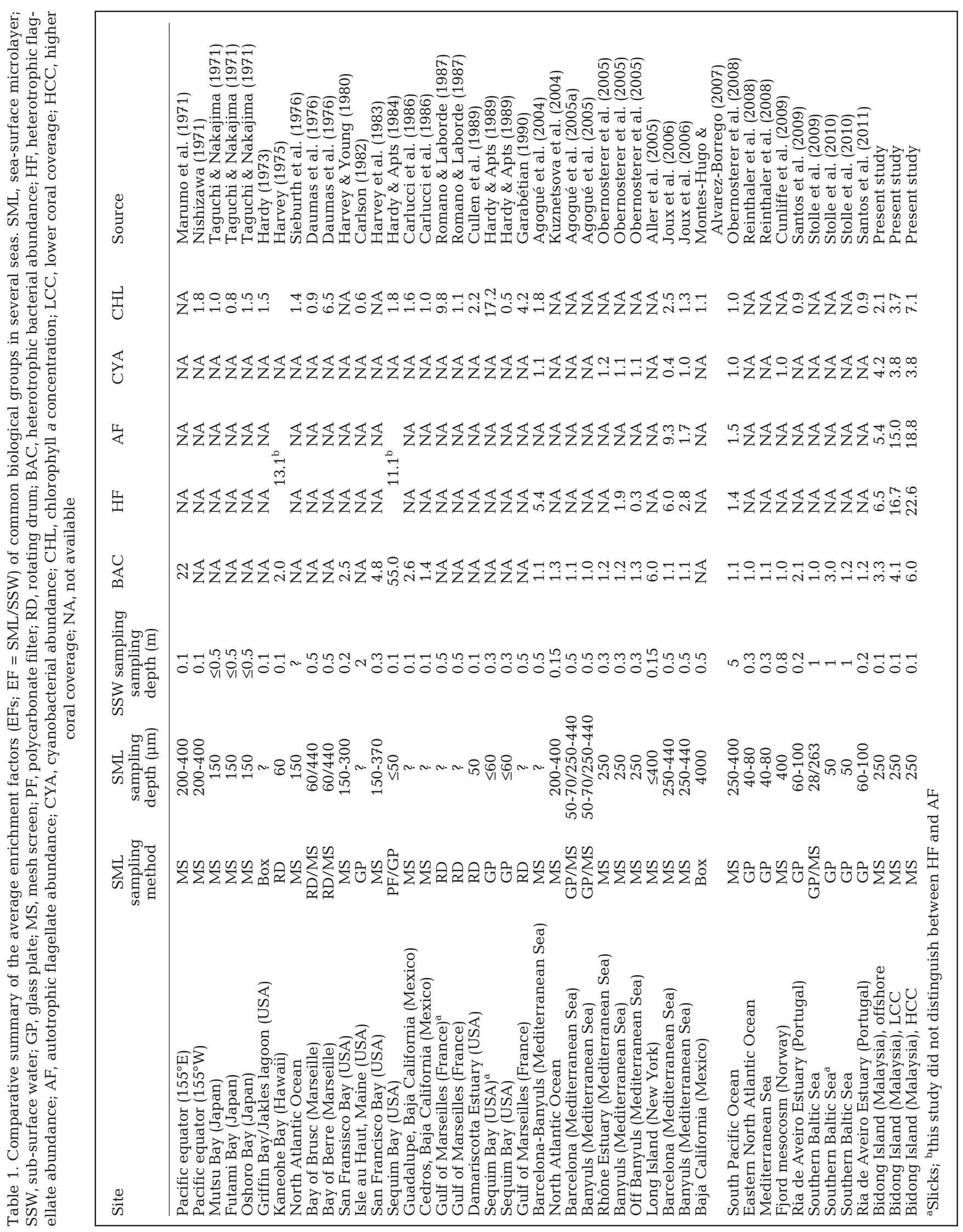




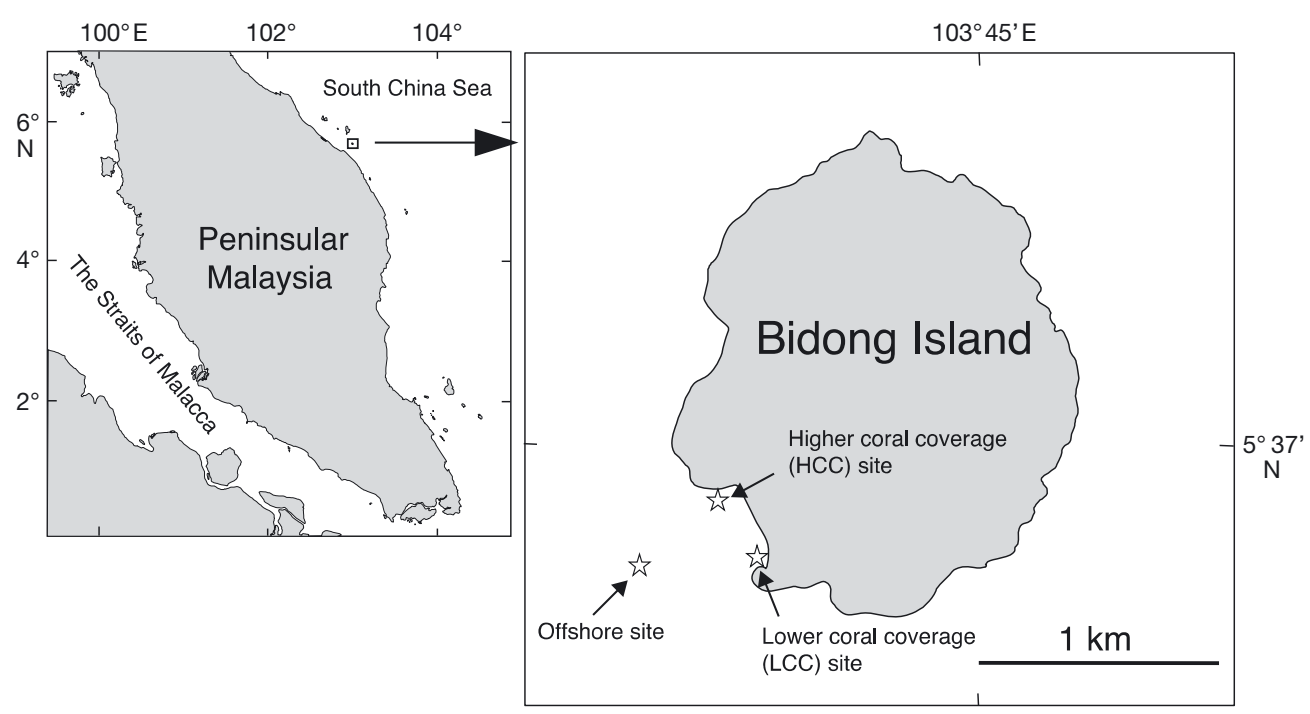

Fig. 1. Sampling sites at Bidong Island, Malaysia. Stars denote the lower coral coverage site (LCC), the higher coral coverage site (HCC) and the offshore site

with no strong wind or rainfall during the sampling period, though we did not measure wind velocity or precipitation.

\section{Sampling}

Samples of the SML and the SSW (10 cm depth) were taken from a small boat. SML samples were taken with a metal mesh sampler according to the method of Garrett (1965). The mesh width of the metal screen was $1.25 \mathrm{~mm}$ and the dimension was $60 \times 80 \mathrm{~cm}$. The metal screen collects roughly the upper $250 \mu \mathrm{m}$ water layer (Garrett 1965). The metal screen was immersed at an angle of ca. $45^{\circ}$ in the water and subsequently raised through the surface water layer in a horizontal position. The metal screen was subsequently drained at an angle of $45^{\circ}$. To prevent inclusion of water adhering to the frame, the first $100 \mathrm{ml}$ of water draining from the metal screen was rejected (Obernosterer et al. 2005). All sampling gear was vigorously rinsed several times with the respective sample water prior to sampling. Samples for measurements of dissolved organic carbon (DOC) and chlorophyll a ( $\mathrm{chl}$ a) concentrations were collected in an acid-cleaned PVC bottle (inner volume 2 1). Triplicate samples $(15 \mathrm{ml})$ for heterotrophic bacterial counts, a single sample $(50 \mathrm{ml})$ for bacterial production measurement and duplicate samples $(50 \mathrm{ml})$ for enumeration of cyanobacteria and hetero(HNF) and autotrophic nanoflagellates (ANF) were collected directly into sterilized Corning tubes. The SSW was sampled by submerging either closed Cor- ning tubes or PVC bottles that were opened and filled at $10 \mathrm{~cm}$ depth. Upon collection, the samples were kept in an ice-filled cooler box on the boat and immediately brought back to the field laboratory within $10 \mathrm{~min}$.

Duplicate subsamples $(8 \mathrm{ml})$ for DOC analysis were filtered through $0.22 \mu \mathrm{m}$ filters (Durapore, PVDF, Millipore) following Servais et al. (1989) and sealed into pre-combusted $\left(500^{\circ} \mathrm{C}_{i} 4 \mathrm{~h}\right)$ amber glass ampoules, and stored frozen at $-20^{\circ} \mathrm{C}$ until analysis. Duplicate subsamples $(500 \mathrm{ml})$ for $\mathrm{chl}$ a analysis were filtered onto GF/F filters (Whatman), then immersed in $N, N$ dimethylformamide (DMF) and stored at $-20^{\circ} \mathrm{C}$ until analysis (Suzuki \& Ishimaru 1990). Samples for bacterial production measurement were dispensed into dark tubes $(50 \mathrm{ml})$ and bromodeoxyuridine (BrdU, Sigma) was added (20 nM final conc.) before the start of incubation in situ at $0.1 \mathrm{~m}$ depth for $3 \mathrm{~h}$ according to Hamasaki (2006). BrdU incorporation was halted by adding excess thymidine (Sigma, $100 \mu \mathrm{M}$ final conc.) at the end of the incubation time (Hamasaki 2006).

\section{Sample analysis}

The DOC concentrations were measured by the high temperature combustion method using TOC-5000 analyzer (Shimadzu) following Ogawa et al. (2003). $\mathrm{Chl}$ a concentrations were determined using a fluorometer (Turner Designs 10-AU) according to HolmHansen et al. (1965). Samples for heterotrophic bacterial counts were fixed with buffered formalin $(1 \%$ 
final conc.) and stored at $5^{\circ} \mathrm{C}$ for one week, then stored frozen at $-20^{\circ} \mathrm{C}$ until analysis. Samples for enumeration of cyanobacteria, HNF and ANF were fixed in $1 \%$ glutaraldehyde seawater and stored at $5^{\circ} \mathrm{C}$ until analysis. To enumerate heterotrophic bacteria (hereafter bacteria), 1.6 to $2 \mathrm{ml}$ of the formalinfixed sample was filtered onto a $0.2 \mu \mathrm{m}$ black membrane filter (Isopore, Millipore) and stained with SYBR Gold (Molecular Probes) following Shibata et al. (2006). For cyanobacteria and flagellates, the $50 \mathrm{ml}$ glutaraldyhyde fixed sample was filtered onto a $0.8 \mu \mathrm{m}$ black membrane filter (Isopore, Millipore), and the filter was stained with primulin (Sigma) following Sherr et al. (1993). Bacteria, cyanobacteria and flagellates were counted with an epifluorescence microscope (Axioskop 2 plus, Zeiss) at $\times 1000$ magnification. ANF were distinguished from non-pigmented HNF by autofluorescence signals. For bacteria and cyanobacteria, at least 400 cells were counted per slide, and 20 to 50 microscope fields per slide were scanned for flagellates. A slide for microscopy was prepared for each microorganism sample.

The BrdU incorporation rate by bacteria was measured by antigen-antibody reaction (Steward \& Azam 1999, Hamasaki 2006). Bacterial cell numbers were converted to carbon units using a conversion factor of $20 \mathrm{fg} \mathrm{C} \mathrm{cell}^{-1}$ (Lee \& Fuhrman 1987). Bacterial growth rate $\left(\mathrm{d}^{-1}\right)$ was estimated by dividing bacterial production ( $\mu \mathrm{g} \mathrm{C}^{-1} \mathrm{~d}^{-1}$ ) with biomass $\left(\mu \mathrm{g} \mathrm{C}^{-1}\right.$ ) following Grossmann \& Dieckmann (1994).

\section{Data analysis}

The enrichment factor (EF) was calculated by dividing concentrations or rates determined for the SML by those for the SSW (EF = SML/SSW) following Cunliffe et al. (2011). The statistical difference in the abundance or production of microorganisms and the concentrations of chl $a$ and DOC in the SML and SSW were determined using a Student's $t$-test. The differences between the 3 sampling sites were determined using one-way ANOVA. The normality of the data and homogeneity of variance were examined and verified before ANOVA analysis using a chisquare test and a Bartlett test, respectively. Correlation between HNF and either bacteria or cyanobacteria was assessed by a Spearman rank-order correlation. Differences at $\mathrm{p}<0.05$ were considered significant.

Spatial similarities of the microbial community density between sites (HCC, LCC and offshore) or sampling depth (SML vs. SSW) were graphically depicted using non-metric multidimensional scaling (MDS) and group average clustering was carried out. The similarity matrix obtained from the abundance values was calculated by the Bray-Curtis index (Bray \& Curtis 1957) with fourth-root transformed data. To test for spatial variation in community density, analysis of similarities (ANOSIM, Clarke \& Warwick 1994) was then undertaken. All statistical analyses were conducted with the software PRIMER v. 6 (Plymouth Marine Laboratory, Clarke \& Warwick 2001).

\section{RESULTS}

\section{Enrichment factors}

The values of enrichment factor $(\mathrm{EF})$, which is a measure of the relative increase in the biological and non-biological parameters between the SML and SSW, are shown in Tables $1 \& 2$.

The concentrations of DOC were significantly enriched in the SML compared with the SSW at all sites (Student $t$-test, $\mathrm{p}<0.05$ ) (Fig. 2a, Table 2). The EFs (mean $\pm \mathrm{SD}$ ) of DOC concentration were similar among the sites $(1.2 \pm 0.1$ to $1.3 \pm 0.2)$ with no significant difference among the 3 sites (ANOVA, df $=2$, $F=3.15, \mathrm{p}=0.07$ ).

The concentration of chl a was also significantly enriched in the SML compared to the SSW at all sites (Student $t$-test, $\mathrm{p}<0.05$ ) (Fig. 2b, Table 2) with higher EFs at the HCC site $(2.1 \pm 0.6$ at offshore to $7.1 \pm 4.3$ at $\left.\mathrm{HCC}_{;} \mathrm{ANOVA}, \mathrm{df}=2, F=5.95, \mathrm{p}=0.013\right)$. Similarly, the abundances of cyanobacteria and ANF were significantly enriched in the air-sea interface (Student $t$-test, p $<0.01$ ) with EFs of 3.8 to 4.2 and 5.4 to 18.8 , respectively (Fig. 2c,d, Table 2).

The bacterial abundances were significantly higher in the SML than the SSW in the present study (Student's $t$-test, $\mathrm{p}<0.05$ ) (Fig. 2e, Table 3). The EFs for bacterial abundance increased with increasing coral coverage, ranging from $3.3 \pm 0.8$ at the offshore site to $6.0 \pm 3.1$ at the HCC site, with a significant difference among the 3 sites (ANOVA, df $=2, F=4.36, \mathrm{p}=0.024$ ). The bacterial production was also higher in the SML than SSW (Fig. 2f) at all sites (EF: 1.4 to 1.7), though the differences were not statistically significant (Student's $t$-test, $\mathrm{p}>0.05$ ) (Table 3 ). In contrast, the estimated bacterial growth rate in the SML $\left(0.26 \pm 0.15 \mathrm{~d}^{-1}\right.$ at $\mathrm{HCC}$ to $0.32 \pm 0.04 \mathrm{~d}^{-1}$ at the offshore site) was significantly lower (Student's $t$-test, $\mathrm{p}<0.01$ ) than at the $\operatorname{SSW}\left(0.72 \pm 0.23 \mathrm{~d}^{-1}\right.$ at LCC to $0.81 \pm 0.30 \mathrm{~d}^{-1}$ at HCC) at all sites with EFs of 0.4 to 0.5 (Fig. 2 g, Table 3 ).

The HNF abundances were also significantly higher in the SML than the SSW (Student $t$-test, $\mathrm{p}<0.01$ ) 

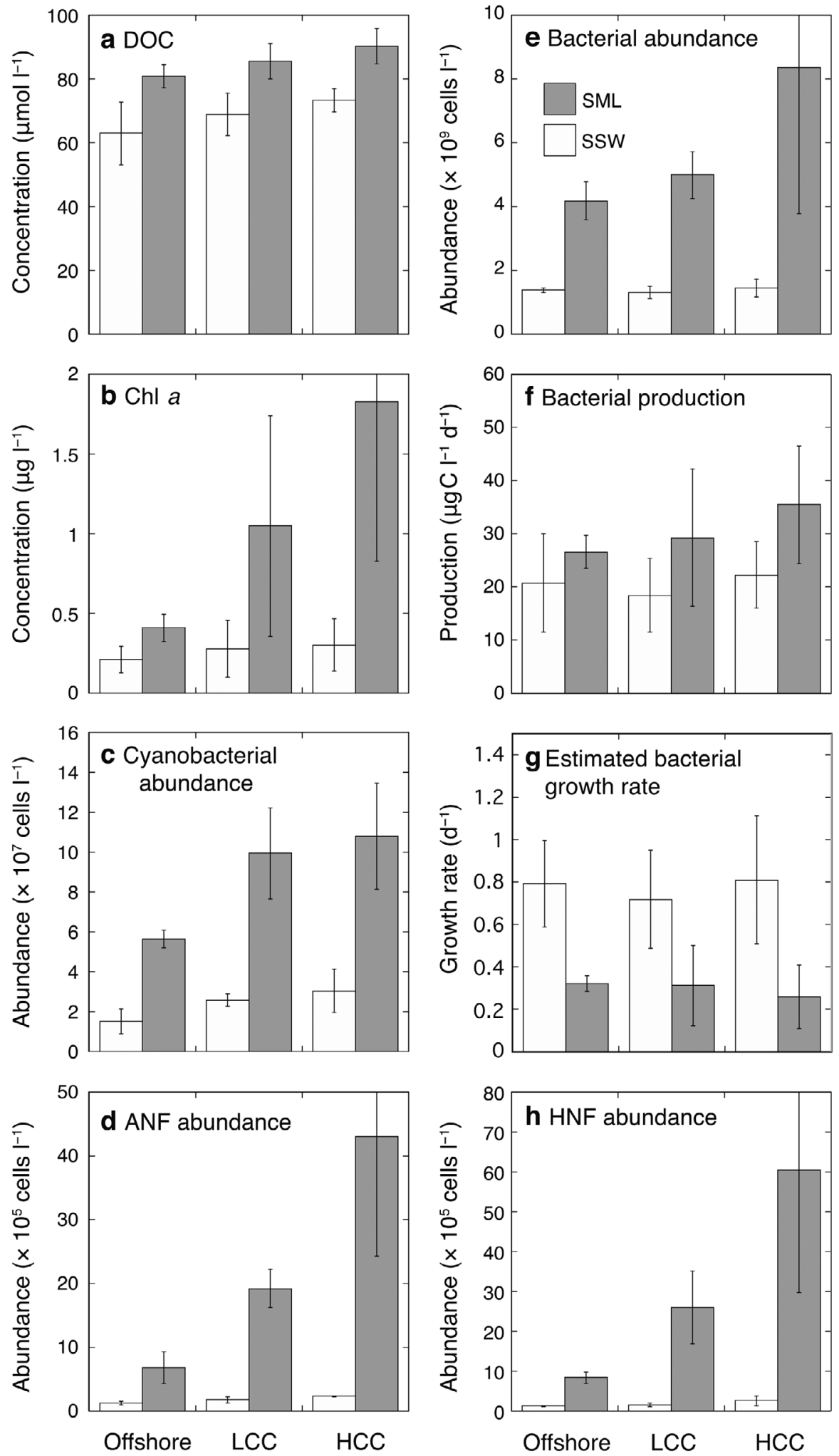

Fig. 2. Concentration (mean $\pm \mathrm{SD}$ ) of (a) dissolved organic carbon (DOC) and (b) chlorophyll a (chl a), as well as abundance of (c) cyanobacteria, (d) autotrophic nanoflagellates (ANF), (e) heterotrophic bacteria and (f) bacterial production, (g) estimated bacterial growth rate, and (h) abundance of heterotrophic nanoflagellates (HNF) in the sea-surface microlayer (SML) and subsurface water (SSW) at 2 coral sites with different coral coverage and an offshore site. Error bars indicate standard deviations for averages for 3 sampling dates. LCC, lower coral coverage site; HCC, higher coral coverage site 
Table 2. Enrichment factors (EFs) for concentration of dissolved organic carbon (DOC) and chlorophyll a (chl a) and abundance of cyanobacteria and autotrophic nanoflagellates (ANF). HCC, higher coral coverage; LCC, lower coral coverage. p-values indicate significant differences in either concentration or abundance between the sea-surface microlayer and sub-surface water

\begin{tabular}{|c|c|c|c|c|c|c|c|c|}
\hline \multirow[t]{2}{*}{ Site } & \multicolumn{2}{|c|}{- DOC -} & \multicolumn{2}{|c|}{$\frac{\mathrm{Chl} \mathrm{a}}{\left(\mathrm{mg} \mathrm{l}^{-1}\right)}$} & \multicolumn{2}{|c|}{$-\underset{\left(\times 10^{7} \text { cells l }^{-1}\right)}{\text { Cyanobacteria }}$} & \multicolumn{2}{|c|}{ ANF -} \\
\hline & $\mathrm{EF}$ & $\mathrm{p}$ & $\mathrm{EF}$ & $\mathrm{p}$ & $\mathrm{EF}$ & $\mathrm{p}$ & $\mathrm{EF}$ & $\mathrm{p}$ \\
\hline $\mathrm{HCC}$ & $\begin{array}{l}1.2 \pm 0.1 \\
(\mathrm{n}=6)\end{array}$ & 0.0028 & $\begin{array}{l}7.1 \pm 4.3 \\
(\mathrm{n}=6)\end{array}$ & 0.0021 & $\begin{array}{l}3.8 \pm 1.0 \\
(\mathrm{n}=6)\end{array}$ & $<0.0001$ & $\begin{array}{l}18.8 \pm 7.2 \\
(\mathrm{n}=6)\end{array}$ & 0.0002 \\
\hline LCC & $\begin{array}{l}1.3 \pm 0.1 \\
(\mathrm{n}=6)\end{array}$ & 0.0013 & $\begin{array}{l}3.7 \pm 0.8 \\
(\mathrm{n}=6)\end{array}$ & 0.0150 & $\begin{array}{l}3.8 \pm 0.5 \\
(\mathrm{n}=6)\end{array}$ & $<0.0001$ & $\begin{array}{l}15.0 \pm 7.3 \\
(\mathrm{n}=6)\end{array}$ & $<0.0001$ \\
\hline Offshore & $\begin{array}{l}1.3 \pm 0.2 \\
(\mathrm{n}=6)\end{array}$ & 0.0041 & $\begin{array}{l}2.1 \pm 0.6 \\
(\mathrm{n}=6)\end{array}$ & 0.0025 & $\begin{array}{l}4.2 \pm 1.3 \\
(\mathrm{n}=6)\end{array}$ & $<0.0001$ & $\begin{array}{l}5.4 \pm 1.3 \\
(\mathrm{n}=6)\end{array}$ & 0.0003 \\
\hline
\end{tabular}

Table 3. Enrichment factors (EFs) for abundance of heterotrophic bacteria and heterotrophic nanoflagellates (HNF), bacteria production and estimated bacterial growth rate. HCC, higher coral coverage; LCC, lower coral coverage. p-values indicate significant differences in either abundance or rate between the sea-surface microlayer and sub-surface water

\begin{tabular}{|c|c|c|c|c|c|c|c|c|}
\hline \multirow[t]{2}{*}{ Site } & \multicolumn{2}{|c|}{$\begin{array}{l}\text { Heterotrophic bacteria } \\
\qquad\left(\times 10^{9} \mathrm{cells}^{-1}\right)\end{array}$} & \multicolumn{2}{|c|}{$\begin{array}{l}\text { Bacterial production } \\
\quad\left(\mu g \mathrm{Cl}^{-1} \mathrm{~d}^{-1}\right)\end{array}$} & \multicolumn{2}{|c|}{$\begin{array}{l}\text { Estimated bacterial growth } \\
\text { rate }\left(\mathrm{d}^{-1}\right)\end{array}$} & \multicolumn{2}{|c|}{$\begin{array}{c}\mathrm{HNF} \\
\left(\times 10^{5}{\left.\text { cells } 1^{-1}\right)}^{-1}\right.\end{array}$} \\
\hline & $\mathrm{EF}$ & $\mathrm{p}$ & EF & $\mathrm{p}$ & $\mathrm{EF}$ & $\mathrm{p}$ & $\mathrm{EF}$ & $\mathrm{p}$ \\
\hline $\mathrm{HCC}$ & $\begin{array}{l}6.0 \pm 3.1 \\
(\mathrm{n}=9)\end{array}$ & 0.0001 & $\begin{array}{l}1.7 \pm 0.2 \\
(\mathrm{n}=3)\end{array}$ & 0.14 & $\begin{array}{l}0.4 \pm 0.1 \\
(\mathrm{n}=3)\end{array}$ & 0.0015 & $\begin{array}{l}22.6 \pm 1.7 \\
(\mathrm{n}=6)\end{array}$ & 0.0004 \\
\hline $\mathrm{LCC}$ & $\begin{array}{l}4.1 \pm 1.3 \\
(\mathrm{n}=9)\end{array}$ & $<0.0001$ & $\begin{array}{l}1.6 \pm 0.1 \\
(\mathrm{n}=3)\end{array}$ & 0.11 & $\begin{array}{l}0.4 \pm 0.1 \\
(\mathrm{n}=3)\end{array}$ & 0.0017 & $\begin{array}{l}16.7 \pm 2.8 \\
(\mathrm{n}=6)\end{array}$ & $<0.0003$ \\
\hline Offshore & $\begin{array}{l}3.3 \pm 0.8 \\
(\mathrm{n}=9)\end{array}$ & $<0.0001$ & $\begin{array}{l}1.4 \pm 0.4 \\
(\mathrm{n}=3)\end{array}$ & 0.34 & $\begin{array}{l}0.5 \pm 0.1 \\
(\mathrm{n}=3)\end{array}$ & 0.0056 & $\begin{array}{l}6.5 \pm 0.8 \\
(\mathrm{n}=6)\end{array}$ & $<0.0001$ \\
\hline
\end{tabular}

(Fig. 2h, Table 3) and higher EFs were observed at the higher coral coverage site compared to the LCC and offshore sites $(6.5 \pm 0.8$ at offshore to $22.6 \pm 1.7$ at HCC; ANOVA, df $=2, F=87, \mathrm{p}=0.006 \times 10^{-6}$ ). There were significant correlations between the cell numbers of HNF and bacteria as well as cyanobacteria (Spearman rank-order correlation, 2-tailed, p < 0.05) (Fig. 3a,b). HNF abundances increased exponentially as numbers of bacteria and cyanobacteria increased. The ratios of bacteria/HNF and cyanobacteria/HNF were low in the SML relative to SSW (Fig. 3c,d), with the ratios in the SML lower in the HCC site.

\section{Ordination of the community density}

The MDS ordination plot with a low stress value $(<0.05)$ and group-average clustering showed that the SML communities were clearly separated from SSW communities (Fig. 4). The communities in the SML were more widely dispersed relative to coral coverage than those in SSW. The result of ANOSIM test showed that the community density between SML and SSW was significantly different (Global R = $0.919, \mathrm{p}=0.001)$.

\section{DISCUSSION}

This paper presents to what extent microorganisms are enriched in the air-sea interface compared to the sub-surface water in coral reef ecosystems. Although we investigated only 2 coral sites and an offshore (non-coral) site in the present study, enrichment was significant in the SML over the SSW for every biological parameter (except bacterial production and growth rate) at all sites, and the EFs increased with increasing coral coverage. For the MDS and ANOSIM analyses, the microbial community density was significantly different between SML and SSW, and the communities among the SML were widely dispersed relative to the coral coverage, supporting the hypothesis that microbial community density in the air-sea interface over coral reefs varies with coral coverage.

As previously reported (reviewed by Cunliffe et al. 2011), the bacterial abundances were significantly higher in the SML than the SSW in the present study. The higher bacterial abundance in the SML could have resulted from production of bacteria in the SML and/or supply of bacteria from the SSW to the SML by diffusion, bulk flow, and adhesion to rising bub- 

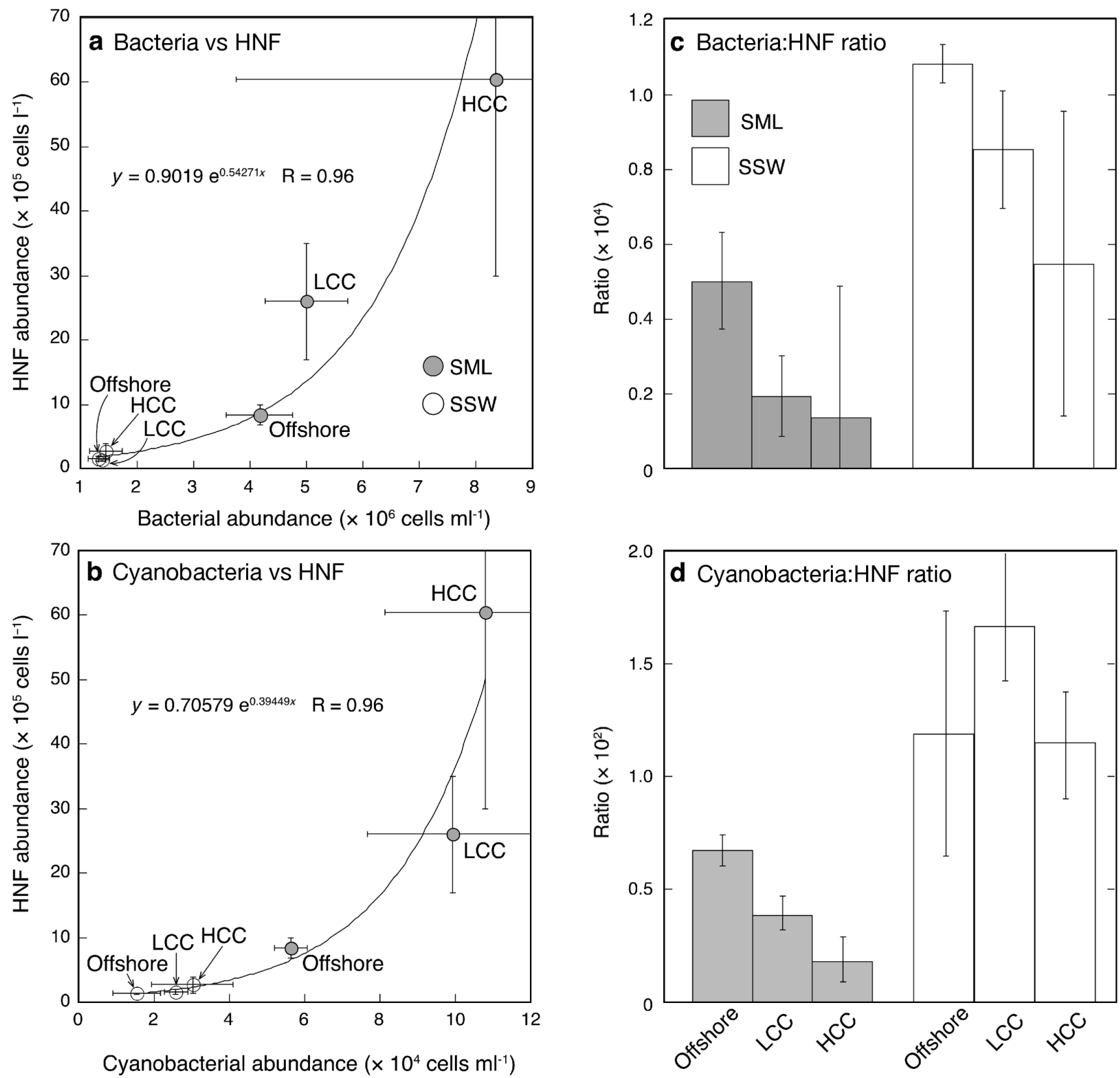

Fig. 3. Correlation between abundance of heterotrophic nanoflagellates (HNF) and either (a) heterotrophic bacteria or (b) cyanobacteria, and ratios of (c) heterotrophic bacteria/HNF and (d) cyanobacteria/HNF in the sea-surface microlayer (SML) and sub-surface water (SSW) at 2 coral sites with different coral coverage (LCC, lower coral coverage site; HCC, higher coral coverage site) and an offshore site. Error bars indicate standard deviations for averages over 3 sampling dates. Curve fitting conducted by exponential function $\left(y=a \times \mathrm{e}^{b x}\right.$, where $x$ is abundance of either bacteria or cyanobacteria and $y$ is HNF abundance) inside KaleidaGraph ${ }^{\circledR}$ Synergy Software package

bles and buoyant particles (Obernosterer et al. 2005). Although the bacterial production was slightly higher in the SML than SSW at all sites, the EFs (1.4 to 1.7) were lower than those for bacterial abundance, suggesting that the SSW may be the major source of bacteria for the SML enrichment rather than bacterial proliferation in the SML. Indeed, the estimated bac- terial growth rate in the SML $\left(0.26\right.$ to $\left.0.32 \mathrm{~d}^{-1}\right)$ was significantly lower than at the SSW (0.72 to $\left.0.81 \mathrm{~d}^{-1}\right)$ at all sites. A possible explanation could be that bacterial growth may be inhibited in the SML as a result of higher exposures to UV radiation and light intensities than in the SSW (Kuznetsova et al. 2004, Agogué et al. 2005b), which is especially plausible in lower 


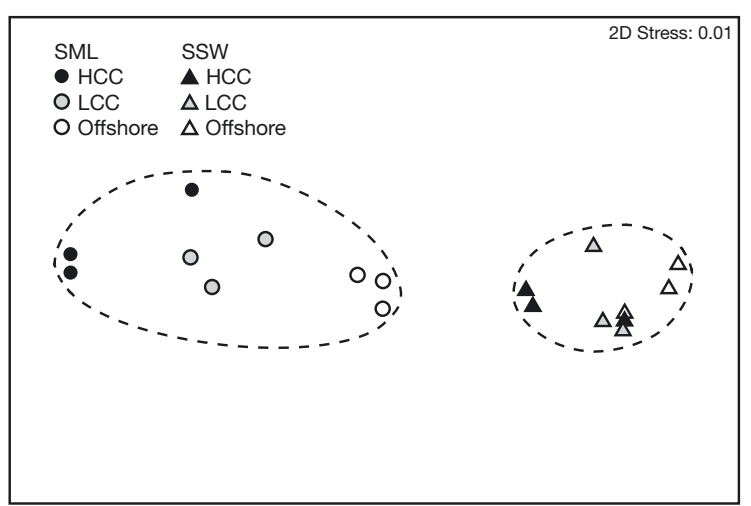

Fig. 4. Non-metric multidimensional scaling (MDS) plots showing similarity of microbial community density in different sites (HCC, higher coral coverage site; LCC, lower coral coverage site, and offshore site) and sampling depth (SML, sea-surface microlayer; SSW, sub-surface water). BrayCurtis similarities were calculated based on fourth-root of abundance. Group-average clusters of $80 \%$ similarity were imposed as dashed lines

latitudes, such as the present study location $\left(05^{\circ} \mathrm{N}\right)$, where light and UV intensities are high (Kuwahara et al. 2010). We incubated SML water collected from the uppermost $250 \mu \mathrm{m}$ layer in situ in the dark condition for measurements of bacterial production. The separation of SML water from its natural environment could have resulted in important changes in the physical properties specific to the air-water interface, especially the intensity of UV radiation (Obernosterer et al. 2005). Our in situ incubations did not take into consideration UV radiation at the sea surface, and the biological processes determined in our experiments probably do not fully represent natural in situ rates. The bacterial production in the SML may be lower than what we obtained if actual UV and light environment in the incubation bottles were taken into consideration. However, we consider our production rate still valid as it was based on a short incubation time $(3 \mathrm{~h})$.

The EFs for bacterial abundance increased with increasing coral coverage, suggesting that the presence of live corals would enhance enrichment of microorganisms in the sea surface. Corals continuously release coral mucus into ambient seawater (e.g. Tanaka et al. 2008, Nakajima et al. 2010) with a relatively large release of mucus during daytime (Naumann et al. 2010), which traps various particles including pelagic bacteria with its sticky surface while it is suspended (Naumann et al. 2009). The upward transport of particle-attached bacteria from the SSW may explain the higher number of bacteria at the $\mathrm{SML}$, as this is reported to represent a significant fraction of the total bacterial numbers at the SML
(Santos et al. 2011). Higher percentages of particleattached bacteria at the SML compared to subsurface water have been observed in different aquatic environments (Harvey \& Young 1980, Aller et al. 2005, Obernosterer et al. 2005, Cunliffe \& Murrell 2009, Santos et al. 2011). The higher concentration of particle-attached bacteria at the SML is construed as due to the upward transport of colonized particles from the water column (Stolle et al. 2010) and/or due to in situ colonization (Cunliffe \& Murrell 2009). Considering the bacterial growth rate was lower at the SML than the SSW in this study, in situ colonization is less likely. Coral mucus often includes air bubbles (byproducts of symbiotic zooxanthellae photosynthesis) that could provide buoyancy, which subsequently accumulate in the sea surface (Wild et al. 2004b), which would be a plausible explanation of the migration of bacterial colonized particle to the surface. Upon secretion, coral mucus already contains a large number of bacteria (i.e. mucus-derived bacteria; Ducklow \& Mitchell 1979), which would also contribute to the higher bacterial abundance in the air-sea interface. The combined transportation of both the mucus-derived bacteria and trapped pelagic bacteria by coral exudates is likely to contribute to the bacterial enrichment in the SML. Although we did not measure particulate organic matter in this study, a higher coral coverage can mean a higher release of mucus derived particles into ambient water, which may be the reason why the EF is higher in the HCC site. Changes in bacterial community composition between the SML and SSW are reported to be stronger in the particle-attached than the non-attached bacteria (Stolle et al. 2011). Thus, a distinct bacterial community may exist in the SML at the HCC site.

Since chl a concentration in the water column was low $\left(<0.3 \mathrm{mg} \mathrm{m}^{-3}\right)$ and there were neither seagrass beds nor mangroves near the reef, the major supply source of DOC would be corals. Although DOC concentrations were significantly enriched in the SML compared with the SSW at all sites, the EFs were similar among the sites (1.2 to 1.3). A relatively large utilization of DOC by bacterial respiration in the SML (Carlson 1983) over the HCC water could be one reason why the EF of DOC was not significantly higher in the HCC site.

HNF was one of the most enriched microorganisms in the SML, showing significantly higher abundances in the SML than the SSW with remarkably high EFs (6.5 to 22.5). HNF abundances increased exponentially as numbers of bacteria and cyanobacteria increased, suggesting that HNF increased by feeding on these organisms. Although grazing rates of these 
flagellates were not measured in the present study, the lower ratios of bacteria/HNF and cyanobacteria/HNF observed in the SML relative to SSW suggests that grazing rates of $\mathrm{HNF}$ on bacteria and cyanobacteria are higher in the SML. As observed in our study, Joux et al. (2006) also reported a lower ratio between bacterial and heterotrophic flagellate abundances in the SML relative to SSW in the northwestern Mediterranean Sea. These results suggest that HNF grazed intensely on bacteria as well as cyanobacteria at the air-sea interface relative to the underlying water. Moreover, all ratios (i.e. bacteria/ HNF and cyanobacteria/HNF) were lower at the HCC site, suggesting that grazing of flagellates on bacteria and cyanobacteria is enhanced in the sea surface with high coral coverage. Because the degree of enrichment of HNF in the SML (6.5 to 22.6) were higher than those for bacteria and cyanobacteria (3.3 to 6.0), HNF may be better adapted to survive and/or proliferate in the SML, due to their higher resistance to stresses like UV radiation (Wängberg et al. 2008). The accumulation and/or proliferation of HNF may have significant consequences for the structure of microbial food webs operating in the SML (Joux et al. 2006), and therefore a remarkable food web and material cycle process may exist at the air-sea boundary over coral reefs.

It is difficult to strictly compare the EFs in our study sites with those from previous studies because of differences in applied methodologies (e.g. differences in sampling devices and sampling depth). Still, if comparisons are to be made, they are as follows (Table 1): the EFs for the abundance of bacteria, cyanobacteria, hetero- and autotrophic flagellates and chl a concentration in the coral reef sites were considerably higher than the other sea environments. For example, the EF of chl a in the HCC site was the highest among the previous studies except for the sites where slicks were observed (Hardy \& Apts 1989, Romano \& Laborde 1987). Similar to chl a concentration, the EFs of cyanobacteria in our study were the highest among the previous studies. With the exceptions of EF $=22$ (Marumo et al. 1971) and 55 (Hardy \& Apts 1984), most of the previous studies reported EFs of bacterial abundance ranging from 1 to 2 , while our values were between 3.0 to 6.0 . The EF of 6.0 in the HCC site was comparable to that in San Francisco Bay (Harvey et al. 1983) and Long Island, USA (Aller et al. 2005). However, it should be noted that most of recent studies on bacterial abundance at the SML used flow cytometry (instead of microscopy) for cell counting (e.g. Agogué et al. 2005a, Joux et al. 2006, Obernosterer et al. 2008,
Reinthaler et al. 2008, Cunliffe et al. 2009, Stolle et al. 2010), where inclined indiscriminate detection of particle-attached bacteria (Obernosterer et al. 2005), may have resulted in lower EFs. Although to the best of our knowledge there are only 8 published studies that reported flagellate numbers in the SML, the EFs of hetero (HF)- and autotrophic flagellates (AF) in our HCC site (22.6 and 18.8, respectively) were the highest among the previous reports. The EF of 13.1 and 11.1 for flagellates (mix of auto- and heterotrophs) observed in Kaneohe Bay (Harvey 1975) and Sequim Bay (Hardy \& Apts 1984) were comparable to those in our LCC site, and the EFs of either HF or AF in Barcelona (Mediterranean Sea; Joux et al. 2006) were comparable to that in our offshore site. Higher microbial heterotrophic metabolism in the SML is known to cause strong $\mathrm{CO}_{2}$ saturation, driving $\mathrm{CO}_{2}$ emission at the air-sea boundary in the top $2 \mathrm{~cm}$ layer (Calleja et al. 2005). The higher microbial abundance in the SML over coral reefs can mean a higher metabolic activity, which potentially influences the gas transfer velocity in the air-sea boundary (Calleja et al. 2005). Higher coral coverage may further magnify this process since microbial activity increases with coral coverage and this could lead to higher $\mathrm{CO}_{2}$ saturation levels, impacting gas exchange between the ocean and atmosphere.

\section{CONCLUSIONS}

We found that the microbial abundances in the SML over coral reefs are significantly enriched compared to the SSW. We also found that the enrichment factors of microorganisms in coral reefs were remarkably higher compared to other marine ecosystems, and a higher concentration of microorganisms was observed in the higher coral coverage site, probably due to the higher organic matter released by corals. The higher microbial abundance in the SML over coral reefs may enhance gaseous exchange and carbon flow in the food web through the air-sea interface. For this reason, quantification of microbial biomass, production and respiration in the air-sea interface over coral reefs would be important in order to better understand the biogeochemical cycle in these ecosystems.

Acknowledgements. We are grateful to S. Taguchi (Soka University) for providing much useful literature and motivation to conduct this research to the first author. We thank 2 anonymous reviewers for their critical reading and valuable comments; L. P. Foong, K. Mizubayashi, B. M. Anderi, B. M. M. Ariff and Captain B. Y. Hassan for field assistance; and N. Yamamoto for help in bacterial counts. This study was par- 
tially funded by the Asian CORE Program of the Japan Society for the Promotion of Science (JSPS), by the UKM Dana Impak Perdana Research Grant DIP-2012-020 and UKM Grant GUP-2012-051, by the Collaborative Research Project for the Next Generation of Soka University, by JSPS KAKENHI Grant (No. 24710013), and by the Environment Research and Technology Development Fund (S9) of the Ministry of the Environment, Japan.

\section{LITERATURE CITED}

Agogué H, Casamayor EO, Joux F, Obernosterer I and others (2004) Comparison of samplers for the biological characterization of the sea surface microlayer. Limnol Oceanogr Methods 2:213-225

Agogué H, Casamayor EO, Bourrain M, Obernosterer I, Joux F, Herndl GJ, Lebaron P (2005a) A survey on bacteria inhabiting the sea surface microlayer of coastal ecosystems. FEMS Microbiol Ecol 54:269-280

Agogué H, Joux F, Obernosterer I, Lebaron P (2005b) Resistance of marine bacterioneuston to solar radiation. Appl Environ Microbiol 71:5282-5289

> Aller JY, Kuznetsova MR, Jahns CJ, Kemp PF (2005) The sea surface microlayer as a source of viral bacterial enrichment in marine aerosols. J Aerosol Sci 36:801-812

> Bray JR, Curtis JT (1957) An ordination of the upland forest communities of southern Wisconsin. Ecol Monogr 27: 325-349

Calleja ML, Duarte CM, Navarro N, Agustí S (2005) Control of air-sea $\mathrm{CO}_{2}$ disequilibria in the subtropical $\mathrm{NE}$ Atlantic by planktonic metabolism under the ocean skin. Geophys Res Lett 32:1-4, doi:10.1029/2004GL022120

> Carlson DJ (1982) Phytoplankton in marine surface microlayers. Can J Microbiol 28:1226-1234

> Carlson DJ (1983) Dissolved organic materials in surface microlayers: temporal and spatial variability and relation to sea state. Limnol Oceanogr 28:415-431

> Carlucci AF, Craven DB, Robertson KJ, Williams PM (1986) Surface film microbial populations: diel amino acid metabolism, carbon utilization, and growth rates. Mar Biol 92:289-297

> Clarke KR, Warwick RM (1994) Similarity-based testing for community pattern: the 2-way layout with no replication. Mar Biol 118:167-176

Clarke KR, Warwick RM (2001) Change in marine communities: an approach to statistical analysis and interpretation, 2nd edn. PRIMER-E, Plymouth

- Crossland CJ (1987) In situ release of mucus and DOC-lipid from the corals Acropora variabilis and Stylophora pistillata in different light regimes. Coral Reefs 6:35-42

> Crossland CJ, Barnes DJ, Borowitzka MA (1980) Diurnal lipid and mucus production in the staghorn coral Acropora acuminata. Mar Biol 60:81-90

Cullen JJ, MacIntyre HL, Carlson DJ (1989) Distributions and photosynthesis of phototrophs in sea-surface films. Mar Ecol Prog Ser 55:271-278

> Cunliffe M, Murrell JC (2009) The sea-surface microlayer is a gelatinous biofilm. ISME J 3:1001-1003

> Cunliffe M, Salter M, Mann PJ, Whiteley AS, Upstill-Goddard RC, Murrell JC (2009) Dissolved organic carbon and bacterial populations in the gelatinous surface microlayer of a Norwegian fjord mesocosm. FEMS Microbiol Lett 299:248-254

Cunliffe M, Upstill-Goddard RC, Murrell JC (2011) Microbiology of aquatic surface microlayers. FEMS Microbiol Rev 35:233-246
Cunliffe M, Engel A, Frka S, Gašparović B and others (2013) Sea surface microlayers: a unified physicochemical and biological perspective of the air-ocean interface. Prog Oceanogr 109:104-116

> Daumas RA, Laborde PL, Marty JC, Saliot A (1976) Influence of sampling method on the chemical composition of water surface film. Limnol Oceanogr 21:319-326

Davies PS (1984) The role of zooxanthellae in the nutritional energy requirements of Pocillopora eydouxi. Coral Reefs 2:181-186

$>$ Davies PS (1991) Effect of daylight variations on the energy budgets of shallow-water corals. Mar Biol 108:137-144

> Ducklow HW, Mitchell R (1979) Bacterial populations and adaptations in the mucus layers on living corals. Limnol Oceanogr 24:715-725

> Falkowski PG, Dubinsky Z, Muscatine L, Porter JW (1984) Light and the bioenergetics of a symbiotic coral. BioScience 34:705-709

Frew NM, Bock EJ, Schimpf U, Hara T and others (2004) Air-sea gas transfer: its dependence on wind stress, small-scale roughness, and surface films. J Geophys Res 109:C08S17, doi:10.1029/2003JC002131

Garabétian $\mathrm{F}$ (1990) $\mathrm{CO}_{2}$ production at the sea-air interface. An approach by the study of respiratory processes in surface microlayer. Int Revue ges Hydrobiol 75:219-229

Garrett WD (1965) Collection of slick-forming materials from the sea surface. Limnol Oceanogr 10:602-605

Grossmann S, Dieckmann GS (1994) Bacterial standing stock, activity, and carbon production during formation and growth of sea ice in the Weddell Sea, Antarctica. Appl Environ Microbiol 60:2746-2753

> Hamasaki K (2006) Comparison of bromodeoxyuridine immunoassay with tritiated thymidine radioassay for measuring bacterial productivity in oceanic waters. J Oceanogr 62:793-799

> Hardy JT (1973) Phytoneuston ecology of a temperate marine lagoon. Limnol Oceanogr 18:525-533

> Hardy JT, Apts CW (1984) The sea-surface microlayer: phytoneuston productivity and effects of atmospheric particulate matter. Mar Biol 82:293-300

- Hardy JT, Apts CW (1989) Photosynthetic carbon reduction: high rates in the sea-surface microlayer. Mar Biol 101: 411-417

Harvey GW (1975) Marine microbial ecology of the sea surface microlayer and nearshore waters. In: Morton B (ed) Proc Special Symp Mar Sci. The Hong Kong Government Printer, Hong Kong, p 104-110

Harvey RW, Young LY (1980) Enrichment and association of bacteria and particulates in salt marsh surface water. Appl Environ Microbiol 39:894-899

> Harvey RW, Lion LW, Young LY (1983) Transport and distribution of bacteria and diatoms in the aqueous surface microlayer of a salt marsh. Estuar Coast Shelf Sci 16: 543-547

Holm-Hansen O, Lorenzen CJ, Holmes RW, Strickland JDH (1965) Fluorometric determination of chlorophyll. ICES J Mar Sci 30:3-15

Jarvis NL (1967) Adsorption of surface-active material at the sea-air interface. Limnol Oceanogr 12:213-221

Joux F, Agogue H, Obernosterer I, Dupuy C, Reinthaler T, Herndl GJ, Lebaron P (2006) Microbial community structure in the sea surface microlayer at two contrasting coastal sites in the northwestern Mediterranean Sea. Aquat Microb Ecol 42:91-104

> Kuwahara VS, Nakajima R, Othman BHR, Kushairi MRM, Toda T (2010) Spatial variability of UVR attenuation and bio-optical factors in shallow coral-reef waters of 
Malaysia. Coral Reefs 29:693-704

Kuznetsova M, Lee C, Aller J, Frew N (2004) Enrichment of amino acids in the sea surface microlayer at coastal and open ocean sites in the North Atlantic Ocean. Limnol Oceanogr 49:1605-1619

Lee S, Fuhrman J (1987) Relationships between biovolume and biomass of naturally derived marine bacterioplankton. Appl Environ Microbiol 53:1298-1303

> Lesser MP, Mazel C, Phinney D, Yentsch CS (2000) Light absorption and utilization by colonies of the congeneric hermatypic corals Montastraea faveolota and Montastaea cavernosa. Limnol Oceanogr 45:76-86

Liss PS, Duce RA (1997) The sea surface and global change. Cambridge University Press, Cambridge

Marumo R, Taga N, Nakai T (1971) Neustonic bacteria and phytoplankton in surface microlayers of the equatorial waters. Bull Plankton Soc Japan 18:36-41

$>$ Montes-Hugo MA, Alvarez-Borrego S (2007) Differences in photosynthetic pigment signatures between phytoneuston and phytoplankton communities in a coastal lagoon of Baja California. Mar Biol 151:1225-1236

- Muscatine L, Falkowski PG, Porter JW, Dubinsky Z (1984) Fate of photosynthetically fixed carbon in light- and shade-adapted colonies of the symbiotic coral Stylophora pistillata. Proc R Soc Lond B Biol Sci 222:181-202

Nakajima R, Yoshida T, Fujita K, Nakayama A, Fuchinoue Y, Othman BHR, Toda T (2010) Release of particulate and dissolved organic carbon by the scleractinian coral Acropora formosa. Bull Mar Sci 86:861-870

Naumann MS, Richter C, el-Zibdah M, Wild C (2009) Coral mucus as an efficient trap for picoplanktonic cyanobacteria: implications for pelagic-benthic coupling in the reef ecosystem. Mar Ecol Prog Ser 385:65-76

> Naumann MS, Hass A, Struck U, Mayr C, el-Zibdah M, Wild C (2010) Organic matter release by dominant hermatypic corals of the Northern Red Sea. Coral Reefs 29:649-659

Nishizawa S (1971) Concentration of organic and inorganic material in the surface skin at the Equator, $155^{\prime} \mathrm{W}$. Bull Plankton Soc Japan 18:42-44

> Obernosterer I, Catala P, Reinthaler T, Herndl GJ, Lebaron P (2005) Enhanced heterotrophic activity in the surface microlayer of the Mediterranean Sea. Aquat Microb Ecol 39:293-302

Obernosterer I, Catala P, Lami R, Caparros J and others (2008) Biochemical characteristics and bacterial community structure of the sea surface microlayer in the South Pacific Ocean. Biogeosciences 5:693-705

- Ogawa H, Usui T, Koike I (2003) Distribution of dissolved oraganic carbon in the East China Sea. Deep-Sea Res II 50:353-366

Reinthaler T, Sintes E, Herndl GJ (2008) Dissolved organic matter and bacterial production and respiration in the sea-surface microlayer of the open Atlantic and the western Mediterranean Sea. Limnol Oceanogr 53:122-136

Romano JC, Laborde P (1987) Small-scale spatial heterogeneity in accumulation structures of particulate material at sea-air interface. Oceanol Acta 10:63-71

Santos AL, Mendes C, Gomes NCM, Henriques I, Correia A, Almeida A, Cunha Â (2009) Short-term variability of abundance, diversity and activity of estuarine bacterioneuston and bacterioplankton. J Plankton Res 31:1545-1555
Santos L, Santos AL, Coelho FJRC, Marcial Gomez NC, Dias JM, Cunha Â, Almeida A (2011) Relation between bacterial activity in the surface microlayer and estuarine hydrodynamics. FEMS Microbiol Ecol 77:636-646

- Servais P, Anzil A, Ventresque C (1989) Simple method for determination of biodegradable dissolved organic carbon in water. Appl Environ Microbiol 55:2732-2734

Sherr EB, Caron DA, Sherr BF (1993) Staining of heterotrophic protists for visualization via epifluorescence microscopy. In: Kemp PF, Sherr BF, Sherr EB, Cole J (eds) Current methods in aquatic microbial ecology. Lewis, New York, NY, p 213-228

Shibata A, Goto Y, Saito H, Kikuchi T, Toda T, Taguchi S (2006) Comparison of SYBR Green I and SYBR Gold stains for enumerating bacteria and viruses by epifluorescence microscopy. Appl Environ Microbiol 43:221-231

Sieburth JM, Willis PJ, Johnson KM, Burney CM and others (1976) Dissolved organic matter and heterotrophic microneustron in the surface microlayers of the North Atlantic. Science 194:1415-1418

> Steward GF, Azam F (1999) Bromodeoxyuridine as an alternative to ${ }^{3} \mathrm{H}$-thymidine for measuring bacterial productivity in aquatic samples. Aquat Microb Ecol 19: $57-66$

> Stolle C, Nagel K, Labrenz M, Jürgens K (2009) Bacterial activity in the sea-surface microlayer: in situ investigations in the Baltic Sea and the influence of sampling devices. Aquat Microb Ecol 58:67-78

> Stolle C, Nagel K, Labrenz M, Jürgens K (2010) Succession of the sea-surface microlayer in the coastal Baltic Sea under natural and experimentally induced low-wind conditions. Biogeosciences 7:2975-2988

> Stolle C, Labrenz M, Meeske C, Jürgens K (2011) Bacterioneuston community structure in the southern Baltic Sea and its dependence on meteorological conditions. Appl Environ Microbiol 77:3726-3733

Suzuki R, Ishimaru T (1990) An improved method for determination of phytoplankton chlorophyll using $N, N$ dimethylformamide. J Oceanogr 46:190-194

Taguchi S, Nakajima K (1971) Plankton and seston in the sea surface of three inlets of Japan. Bull Plankton Soc Japan 18:20-36

Tanaka Y, Miyajima T, Koike I, Hayashibara T, Ogawa H (2008) Production of dissolved and particulate organic matter by the reef-building corals Porites cylindrica and Acropora pulchra. Bull Mar Sci 82:237-245

> Wängberg SÅ, Andreasson KIM, Gustavson K, Reinthaler T, Henriksen P (2008) UV-B effects on microplankton communities in Kongsfjord, Svalbard-a mesocosm experiment. J Exp Mar Biol Ecol 365:156-163

Wild C, Rasheed M, Werner U, Franke U, Johnstone R, Huettel M (2004a) Degradation and mineralization of coral mucus in reef environments. Mar Ecol Prog Ser 267:159-171

Wild C, Huettel M, Klueter A, Kremb SG, Rasheed M, Jørgenssen BB (2004b) Coral mucus functions as an energy carrier and particle trap in the reef ecosystem. Nature 428:66-70

Wild C, Naumann M, Niggl W, Haas A (2010) Carbohydrate composition of mucus released by scleractinian warmand cold-water reef corals. Aquat Biol 10:41-45

Submitted: March 19, 2013; Accepted: July 17, 2013

Proofs received from author(s): September 5, 2013 